\title{
Mechanisms of Regulatory B cell Function in Autoimmune and Inflammatory Diseases beyond IL-10
}

\author{
Avijit Ray ${ }^{1,2}$ and Bonnie N. Dittel 1,3,* \\ 1 Blood Center of Wisconsin, Blood Research Institute, Milwaukee, WI 53226, USA; rayavijit@gmail.com \\ Oncology Discovery, AbbVie Inc., North Chicago, IL 60064, USA \\ 3 Department of Microbiology and Molecular Genetics, Medical College of Wisconsin, Milwaukee, \\ WI 53226, USA \\ * Correspondence: bonnie.dittel@bcw.edu; Tel.: +1-414-937-3865
}

Academic Editor: Emmanuel Andrès

Received: 20 December 2016; Accepted: 19 January 2017; Published: 23 January 2017

\begin{abstract}
In the past two decades it has become clear that in addition to antigen presentation and antibody production B cells play prominent roles in immune regulation. While B cell-derived IL-10 has garnered much attention, B cells also effectively regulate inflammation by a variety of IL-10-independent mechanisms. B cell regulation has been studied in both autoimmune and inflammatory diseases. While collectively called regulatory B cells (Breg), no definitive phenotype has emerged for B cells with regulatory potential. This has made their study challenging and thus unique B cell regulatory mechanisms have emerged in a disease-dependent manner. Thus to harness the therapeutic potential of Breg, further studies are needed to understand how they emerge and are induced to evoke their regulatory activities.
\end{abstract}

Keywords: B cell; immune regulation; autoimmunity; inflammation

\section{Introduction}

Although B cells play a crucial role in mounting an immune response, they also possess immune-regulatory properties that have been elucidated extensively in the last decade [1]. Numerous studies have documented resolution of immune responses by varied subsets of B cells collectively referred to as regulatory B cells (Breg) [1]. Interestingly, Breg come in a variety of flavors differing in their phenotype, location and functional modality [2]. Although most studies have been focused on IL-10-mediated regulation by Breg, which have been extensively reviewed $[3,4]$, other mechanisms including but not limited to GITRL-mediated regulatory T cell (Treg) maintenance, IL-35 and TGF- $\beta$ production and adenosine generation via CD73 have also been well documented [5]. In this review, we will discuss IL-10-independent mechanisms of Breg function in the context of autoimmune and inflammatory diseases (Table 1). 
Table 1. Regulatory B cell mechanisms independent of IL-10.

\begin{tabular}{|c|c|c|c|}
\hline Disease & Breg Phenotype & Mechanism of Action & Refs. \\
\hline \multirow{5}{*}{ EAE } & Splenic & GITRL-mediated homeostatic maintenance of Treg & [6] \\
\hline & $\mathrm{CD} 19^{+} \mathrm{CD} 23^{\mathrm{Hi}} \mathrm{MLN}$ & Unknown & {$[7]$} \\
\hline & $\mathrm{PD}_{\mathrm{L} 1}{ }^{+}$ & Upregulation of PD-1 on Treg & {$[8,9]$} \\
\hline & $\mathrm{PD}-\mathrm{L} 1{ }^{\mathrm{Hi}}$ & Restriction of $\mathrm{T}$ cell differentiation & [10] \\
\hline & IL-35-producing & IL-35 production & {$[11]$} \\
\hline Diabetes & LPS-activated & FasL-mediated apoptosis of pathogenic T cells and TGF- $\beta$ & [12] \\
\hline \multirow{4}{*}{ Colitis } & B1 & Natural IgM & {$[13,14]$} \\
\hline & Splenic & $\begin{array}{c}\text { Probably via TGF- } \beta \text {-mediated regulation of inflammatory } \\
\text { macrophages }\end{array}$ & [15] \\
\hline & B1 & CD73 generation of adenosine & [16] \\
\hline & Unknown & Treg induced production of IgA & {$[17]$} \\
\hline \multirow{4}{*}{$\begin{array}{l}\text { Transplant } \\
\text { tolerance }\end{array}$} & ICAM-1 ${ }^{\mathrm{Hi}}$ & TGF- $\beta$ mediated expansion of Treg & {$[18,19]$} \\
\hline & Transitional-2 & Unknown & [20] \\
\hline & $\mathrm{F}_{\mathrm{C}} \gamma \mathrm{RIIB}^{\mathrm{Hi}}$ & Unknown & [21] \\
\hline & FasL $^{+}$ & Possibly Fas: FasL-mediated killing of effector T cell & {$[22]$} \\
\hline CIA & $\mathrm{FasL}^{+} \mathrm{CD}^{+}$ & T cell apoptosis via Fas: FasL & [23] \\
\hline
\end{tabular}

\section{Experimental Autoimmune Encephalomyelitis (EAE)}

Using the EAE mouse model of the central nervous system autoimmune disease multiple sclerosis (MS), we provided the first evidence that B cells play a regulatory role in autoimmunity [24]. Specifically, we showed that B cell-deficient B10.PL mice immunized with the immunodominant myelin basic protein peptide Ac1-11 were unable to recover from the signs of EAE [24]. This seminal finding was confirmed using a similar strategy in C57BL/ 6 mice, which indicated a role for IL-10 in B cell regulation [25]. We also reproduced these results in the adoptive transfer model of EAE in B10.PL mice [26]. Given that B cell depletion in humans using antibodies specific for CD20 (rituximab) has clinical relevance in relapsing and remitting MS $[27,28]$, we utilized the same strategy and found that $\mathrm{B}$ cell depletion prior to the onset of EAE also resulted in chronic EAE induced by adoptive transfer in B10.PL mice [6]. This same result was obtained in the $\mathrm{MOG}_{35-55}$ model of EAE in C57BL/6 mice [29,30]. Interestingly, B cell depletion during EAE progression suppressed disease severity, suggesting that B cells can also play a pathogenic role in EAE [29,31]. Mechanisms contributing to $B$ cell pathogenesis demonstrated experimentally in EAE include antigen presentation and IL-6 production [31,32]. However, the absence of $B$ cells did not alter the EAE disease course in relapsing and remitting EAE in $(\mathrm{B} 10 / \mathrm{PLxSJL} / \mathrm{J}) \mathrm{F}_{1}$ mice [33]. These collective data indicate that $\mathrm{B}$ cells are not required for the initiation of disease, but likely play a role in progression of disease by a combination of antigen presentation and proinflammatory cytokine production. To date no definitive Breg markers have been identified, so determining when they emerge and where they exert their regulation has not been possible.

In subsequent studies, we have extensively studied the role of B cells in the context of EAE and were one of the first to identify an IL-10-independent mechanism of action of Breg [6]. In addition, we found that Breg regulation during EAE was also independent of antigen presentation [6]. Our investigations identified B cell involvement in the peripheral maintenance of Foxp $3^{+}$regulatory $\mathrm{T}$ cells (Treg), as genetic or antibody-mediated (anti-CD20) ablation of B cells resulted in significantly reduced numbers of Tregs in the periphery, without affecting their development in the thymus [6]. The reduction in Treg was correlated with the inability to resolve EAE leading to chronic disease [6]. Further investigation revealed a role for B cells in inducing Treg proliferation thereby contributing to their peripheral homeostasis via glucocorticoid-induced tumor necrosis factor-related receptor (GITR)-ligand (GITRL) [6]. Antibody-mediated blocking of GITRL on B cells abolished their Treg maintenance resulting in chronic EAE [6]. Further evidence supporting a role for GITRL expression by $B$ cells driving Treg proliferation is the finding that transgenic mice over expressing GITRL in B cells 
have increased numbers of Treg [34]. A finding we recently confirmed in our animal colony using the same mice (Gurski and Dittel, unpublished observations).

Of interest, we found that B cell-derived IL-10 was not required for their ability to induce Treg proliferation [6]. Similarly, it was found that $\mathrm{CD} 19^{+} \mathrm{CD} 23^{+}$Breg induced by Helminths, ameliorated EAE independent of IL-10 [7]. Recently, a mechanism of Breg function involving programmed death 1 (PD-1) and its ligand PD-L1 has also been observed [8]. It was found that adoptive transfer of PD-L1 ${ }^{\mathrm{Hi}}$ $B$ cells resolved EAE by negatively regulating T cell differentiation [10]. Interestingly, PD-1 is highly expressed on Treg [35] and thus modulation of Treg by PD-L1 ${ }^{\mathrm{Hi}} \mathrm{B}$ cells is a possibility. Indeed, it was shown that estrogen treatment, that resolves EAE [36], upregulated PD-1 on Treg [9], which was dependent on PD-L1 expression on B cells [8]. Apart from costimulatory molecules, recently it has been shown that Breg also utilize the cytokine IL-35 in regulating immune response in the context of EAE, although this mechanism is not independent of IL-10 [11]. B cells required both cytokines for resolving EAE as deficiency in either IL-35 or IL-10 abrogated the regulatory potential of B cells [11]. Mainly, the $\mathrm{CD} 138^{\mathrm{Hi}}$ antibody-secreting cells displayed this regulatory property via secretion of both IL-10 and IL-35 and they also dampened host immunity against infectious disease [11]. In a separate study, it was shown that B cells produce IL-35 in response to IL-35 stimulation and can control experimental uveitis [37]. Interestingly, Treg also produce IL-35 [38] and thus Treg-mediated generation of IL-35-producing Breg is a possibility suggesting cooperation between these two regulatory cell populations, as also observed by us [6].

The above collective data indicate that B cells play dual roles in EAE both in resolving CNS-directed autoimmunity and in promoting disease progression. Even though anti-CD20 depletion with rituximab has clinical relevance in MS, the exact mechanism(s) whereby B cell depletion is therapeutic in MS is not known. One mechanism that has largely been eliminated is a role for pathogenic antibodies, given that rituximab does not deplete plasma cells due their lack of CD20 expression. It is conceivable that pathogenic B cells are depleted thereby limiting subsequent relapses due to reduced antigen presentation to myelin-specific $\mathrm{T}$ cells or the production of proinflammatory cytokines. On the other hand, rituximab may either spare Breg subsets or that they are the first to emerge from the bone marrow following B cell depletion thus becoming the dominant B cell population, a mechanism that would also limit inflammation and subsequent relapses. While rituximab can reduce $B$ cell numbers nearly to zero in the peripheral blood this does not occur in all patients [39]. In addition, based on mouse studies using B cell depletion with anti-CD20, depending on the isotype of antibody used, splenic B cells populations are not completely depleted [40]. Thus, we propose that Breg subsets are spared in the spleens of rituximab-treated MS patients where they maintain Treg cell numbers that in turn suppress T cell activation leading to relapses in MS. These data are consistent with the finding that Treg numbers are not altered following rituximab administration [41].

\section{Type 1 Diabetes (T1D)}

The dual role of B cells is very apparent in Type 1 diabetes (T1D) where insulin-producing B cells in the pancreas are targeted and damaged by self-reactive immune cells. In nonobese diabetic (NOD) mice, a model for T1D, although B cells initiate the autoimmune response via production of self-reactive antibodies, they also display a regulatory role. Activation via lipopolysaccharide (LPS), induced FasL expression and TGF- $\beta$ secretion by B cells, which when adoptively transferred to NOD mice prevented the onset of disease [12]. Mechanistically, the activated B cells induced FasL-mediated apoptosis of self-reactive T cells and dampened the function of antigen presenting cells via TGF- $\beta$ [12]. However, B cell depletion therapies have shown positive outcomes in NOD mice [42] and human trials [43], suggesting that the pathogenic role of B cells outweighs their regulatory potential in T1D.

\section{Colitis}

In a spontaneous enterocolitis model using $\mathrm{TCR} \alpha^{-/-}$mice, absence of B cells exacerbated disease [44] and the mechanism of Breg function was attributed to natural IgM production by B1 
cells in response to commensals [13]. Although B1 cells are potent producers of IL-10 [45], in this study, there was no detectable change in IL-10 production by B cells either exposed to commensals or not. Commensal mediated IgM production by B cells was also implicated in Breg function in a model of colonic inflammation induced by dextran sodium sulfate (DSS) [14]. Apart from commensals, Hymenolepis diminuta infection also generated Breg that could control DSS-colitis probably via TGF- $\beta$-mediated regulation of inflammatory macrophages [15]. Also, CD73-mediated generation of adenosine has been implicated in the regulatory function of B1 B cell in DSS-colitis [16]. Interestingly, it was found that adenosine production was reduced when B cells were deficient in IL-10 [16], although whether IL-10-mediated regulation of CD73 expression occurs is not known. Interestingly, Treg express the adenosine receptor $[46,47]$, which could be activated by adenosine generated by Breg. This suggests interplay between Breg and Treg for controlling an immune response, which was also observed by us in DSS-colitis [17]. Specifically, we observed a regulatory role for B cells in controlling DSS-colitis via their interaction with Treg which in turn induced IgA production by B cells [17].

\section{Transplant Tolerance}

In a cardiac allograft model, anti-CD45RB treatment prevented graft rejection, which was shown to be dependent on the presence of B cells [48]. B cell deficiency ameliorated the efficacy of anti-CD45RB therapy in promoting graft tolerance, which was restored by reconstituting the host with $B$ cells via adoptive transfer [48]. Anti-CD45RB treatment upregulated ICAM-1 on B cells that was required for the immune regulation by B cells [18] whilst IL-10 production was indispensable [49]. Further investigation revealed TGF- $\beta$-mediated expansion of Treg as the mechanism of Breg function in this model [19]. Similarly, in a MHC I mismatch skin graft model, transitional-2 B cells from tolerized mice were immunosuppressive and prolonged graft survival upon adoptive transfer, even when deficient in IL-10 production [20]. In another long-term cardiac allograft model, $\mathrm{Fc} \gamma \mathrm{RIIB}{ }^{\mathrm{Hi}} \mathrm{B}$ cells accumulated over time and were involved in immune regulation preventing graft rejection (47). In addition, in a male-to-female skin graft model FasL ${ }^{+} \mathrm{B}$ cells mediated immune tolerance resulting in acceptance of male skin grafts by female recipients [22]. Deficiency in FasL on B cells abrogated their tolerogenic potential [22]. Although not investigated, a probable mechanism is B cell-mediated apoptosis of Fas expressing effector T cells via Fas-FasL interactions, a mechanism also observed in an animal model of rheumatoid arthritis (RA), collagen-induced arthritis (CIA).

\section{CIA}

In CIA, B cell-mediated immune regulation through induction of apoptosis in pathogenic $\mathrm{T}$ cells via Fas-FasL is suggested [23]. In this model increased disease severity was correlated with reduced presence of $\mathrm{FasL}^{+} \mathrm{CD}^{+} \mathrm{B}$ cells and decreased $\mathrm{T}$ cell death [23]. Interestingly, $\mathrm{CD}^{+} \mathrm{B} 1$ cells are also potent producers of IL-10 [45] and in this study dependency of Breg on this cytokine was not evaluated. Thus a possibility exists for codependence of Breg function on both FasL expression and IL-10 production, as with IL-35-producing Bregs in EAE [11].

\section{Conclusions}

Although a regulatory role for B cells is well established, much needs to be elucidated regarding their origin, phenotype and function. The variety in phenotype, mechanism of action, and location of B cells with suppressive ability suggest that unlike Treg, Breg are not a distinct lineage. Rather, depending on the context, B cells can either, transiently or permanently, display regulatory potential for suppressing an immune response and prevent immune pathology. Thus, it is important to identify the cues that lead to the generation of Breg to facilitate the therapeutically harnessing the potential of these cells in controlling immune responses.

Acknowledgments: This work was supported by grants awarded to B.N.D. by the National Institutes of Health (R01 AI069358, 1R56AI122655) and the National Multiple Sclerosis Society (RG 1501-03034) and the Blood Center Research Foundation. 
Author Contributions: A.R. drafted the manuscript and B.N.D. made final edits.

Conflicts of Interest: The authors declare no conflict of interest.

\section{References}

1. Mauri, C.; Bosma, A. Immune regulatory function of B cells. Annu. Rev. Immunol. 2012, 30, $221-241$. [CrossRef] [PubMed]

2. Rosser, E.C.; Mauri, C. Regulatory B cells: Origin, phenotype, and function. Immunity 2015, 42, 607-612. [CrossRef] [PubMed]

3. Mizoguchi, A.; Bhan, A.K. A case for regulatory B cells. J. Immunol. 2006, 176, 705-710. [CrossRef] [PubMed]

4. Candando, K.M.; Lykken, J.M.; Tedder, T.F. B10 cell regulation of health and disease. Immunol. Rev. 2014, 259, 259-272. [CrossRef] [PubMed]

5. Ray, A.; Wang, L.; Dittel, B.N. IL-10-independent regulatory B-cell subsets and mechanisms of action. Int. Immunol. 2015, 27, 531-536. [CrossRef] [PubMed]

6. Ray, A.; Basu, S.; Williams, C.B.; Salzman, N.H.; Dittel, B.N. A novel IL-10-independent regulatory role for B cells in suppressing autoimmunity by maintenance of regulatory T cells via GITR ligand. J. Immunol. 2012, 188, 3188-3198. [CrossRef] [PubMed]

7. Wilson, M.S.; Taylor, M.D.; O'Gorman, M.T.; Balic, A.; Barr, T.A.; Filbey, K.; Anderton, S.M.; Maizels, R.M. Helminth-induced $\mathrm{CD} 19^{+} \mathrm{CD} 23^{\text {hi }} \mathrm{B}$ cells modulate experimental allergic and autoimmune inflammation. Eur. J. Immunol. 2010, 40, 1682-1696. [CrossRef] [PubMed]

8. Bodhankar, S.; Galipeau, D.; Vandenbark, A.A.; Offner, H. PD-1 Interaction with PD-L1 but not PD-L2 on B-cells mediates protective effects of estrogen against EAE. J. Clin. Cell. Immunol. 2013, 4, 143. [CrossRef] [PubMed]

9. Bodhankar, S.; Vandenbark, A.A.; Offner, H. Oestrogen treatment of experimental autoimmune encephalomyelitis requires $17 \beta$-oestradiol-receptor-positive B cells that up-regulate PD-1 on CD4 ${ }^{+}$Foxp3 $^{+}$ regulatory T cells. Immunology 2012, 137, 282-293. [CrossRef] [PubMed]

10. Khan, A.R.; Hams, E.; Floudas, A.; Sparwasser, T.; Weaver, C.T.; Fallon, P.G. PD-L1 ${ }^{\text {hi }}$ B cells are critical regulators of humoral immunity. Nat. Commun. 2015, 6, 5997. [CrossRef] [PubMed]

11. Shen, P.; Roch, T.; Lampropoulou, V.; O'Connor, R.A.; Stervbo, U.; Hilgenberg, E.; Ries, S.; Dang, V.D.; Jaimes, Y.; Daridon, C.; et al. IL-35-producing B cells are critical regulators of immunity during autoimmune and infectious diseases. Nature 2014, 507, 366-370. [CrossRef] [PubMed]

12. Tian, J.; Zekzer, D.; Hanssen, L.; Lu, Y.; Olcott, A.; Kaufman, D.L. Lipopolysaccharide-activated B cells down-regulate Th1 immunity and prevent autoimmune diabetes in nonobese diabetic mice. J. Immunol. 2001, 167, 1081-1089. [CrossRef] [PubMed]

13. Shimomura, Y.; Mizoguchi, E.; Sugimoto, K.; Kibe, R.; Benno, Y.; Mizoguchi, A.; Bhan, A.K. Regulatory role of B-1 B cells in chronic colitis. Int. Immunol. 2008, 20, 729-737. [CrossRef] [PubMed]

14. Kirkland, D.; Benson, A.; Mirpuri, J.; Pifer, R.; Hou, B.; DeFranco, A.L.; Yarovinsky, F. B cell-intrinsic MyD88 signaling prevents the lethal dissemination of commensal bacteria during colonic damage. Immunity 2012, 36, 228-238. [CrossRef] [PubMed]

15. Reyes, J.L.; Wang, A.; Fernando, M.R.; Graepel, R.; Leung, G.; van Rooijen, N.; Sigvardsson, M.; McKay, D.M. Splenic B cells from Hymenolepis diminuta-infected mice ameliorate colitis independent of T cells and via cooperation with macrophages. J. Immunol. 2015, 194, 364-378. [CrossRef] [PubMed]

16. Kaku, H.; Cheng, K.F.; Al-Abed, Y.; Rothstein, T.L. A novel mechanism of B cell-mediated immune suppression through CD73 expression and adenosine production. J. Immunol. 2014, 193, 5904-5913. [CrossRef] [PubMed]

17. Wang, L.; Ray, A.; Jiang, X.; Wang, J.Y.; Basu, S.; Liu, X.; Qian, T.; He, R.; Dittel, B.N.; Chu, Y. T regulatory cells and B cells cooperate to form a regulatory loop that maintains gut homeostasis and suppresses dextran sulfate sodium-induced colitis. Mucosal Immunol. 2015, 8, 1297-1312. [CrossRef] [PubMed]

18. Huang, X.; Moore, D.J.; Mohiuddin, M.; Lian, M.M.; Kim, J.I.; Sonawane, S.; Wang, J.; Gu, Y.; Yeh, H.; Markmann, J.F.; et al. Inhibition of ICAM-1/LFA-1 interactions prevents B-cell-dependent anti-CD45RB-induced transplantation tolerance. Transplantion 2008, 85, 675-680. [CrossRef] [PubMed] 
19. Lee, K.M.; Stott, R.T.; Zhao, G.; SooHoo, J.; Xiong, W.; Lian, M.M.; Fitzgerald, L.; Shi, S.; Akrawi, E.; Lei, J.; et al. TGF- $\beta$-producing regulatory $\mathrm{B}$ cells induce regulatory $\mathrm{T}$ cells and promote transplantation tolerance. Eur. J. Immunol. 2014, 44, 1728-1736. [CrossRef] [PubMed]

20. Moreau, A.; Blair, P.A.; Chai, J.G.; Ratnasothy, K.; Stolarczyk, E.; Alhabbab, R.; Rackham, C.L.; Jones, P.M.; Smyth, L.; Elgueta, R.; et al. Transitional-2 B cells acquire regulatory function during tolerance induction and contribute to allograft survival. Eur. J. Immunol. 2015, 45, 843-853. [CrossRef] [PubMed]

21. Le Texier, L.; Thebault, P.; Lavault, A.; Usal, C.; Merieau, E.; Quillard, T.; Charreau, B.; Soulillou, J.P.; Cuturi, M.C.; Brouard, S.; et al. Long-term allograft tolerance is characterized by the accumulation of B cells exhibiting an inhibited profile. Am. J. Transplant. 2011, 11, 429-438. [CrossRef] [PubMed]

22. Minagawa, R.; Okano, S.; Tomita, Y.; Kishihara, K.; Yamada, H.; Nomoto, K.; Shimada, M.; Maehara, Y.; Sugimachi, K.; Yoshikai, Y.; et al. The critical role of Fas-Fas ligand interaction in donor-specific transfusion-induced tolerance to H-Y antigen. Transplantion 2004, 78, 799-806. [CrossRef]

23. Lundy, S.K.; Fox, D.A. Reduced Fas ligand-expressing splenic CD5 ${ }^{+}$B lymphocytes in severe collagen-induced arthritis. Arthritis Res. Ther. 2009, 11, R128. [CrossRef] [PubMed]

24. Wolf, S.D.; Dittel, B.N.; Hardardottir, F.; Janeway, C.A., Jr. Experimental autoimmune encephalomyelitis induction in genetically B cell-deficient mice. J. Exp. Med. 1996, 184, 2271-2278. [CrossRef] [PubMed]

25. Fillatreau, S.; Sweenie, C.H.; McGeachy, M.J.; Gray, D.; Anderton, S.M. B cells regulate autoimmunity by provision of IL-10. Nat. Immunol. 2002, 3, 944-950. [CrossRef] [PubMed]

26. Mann, M.K.; Maresz, K.; Shriver, L.P.; Tan, Y.; Dittel, B.N. B cell regulation of CD4 ${ }^{+} \mathrm{CD} 25^{+}$T regulatory cells and IL-10 via B7 is essential for recovery from experimental autoimmune encephalomyelitis. J. Immunol. 2007, 178, 3447-3456. [CrossRef] [PubMed]

27. Hauser, S.L.; Waubant, E.; Arnold, D.L.; Vollmer, T.; Antel, J.; Fox, R.J.; Bar-Or, A.; Panzara, M.; Sarkar, N.; Agarwal, S.; et al. B-cell depletion with rituximab in relapsing-remitting multiple sclerosis. N. Engl. J. Med. 2008, 358, 676-688. [CrossRef] [PubMed]

28. Naismith, R.T.; Piccio, L.; Lyons, J.A.; Lauber, J.; Tutlam, N.T.; Parks, B.J.; Trinkaus, K.; Song, S.K.; Cross, A.H. Rituximab add-on therapy for breakthrough relapsing multiple sclerosis: A 52-week phase II trial. Neurology 2010, 74, 1860-1867. [CrossRef] [PubMed]

29. Matsushita, T.; Yanaba, K.; Bouaziz, J.D.; Fujimoto, M.; Tedder, T.F. Regulatory B cells inhibit EAE initiation in mice while other B cells promote disease progression. J. Clin. Investig. 2008, 118, 3420-3430. [CrossRef] [PubMed]

30. Weber, M.S.; Prod'homme, T.; Patarroyo, J.C.; Molnarfi, N.; Karnezis, T.; Lehmann-Horn, K.; Danilenko, D.M.; Eastham-Anderson, J.; Slavin, A.J.; Linington, C.; et al. B-cell activation influences T-cell polarization and outcome of anti-CD20 B-cell depletion in central nervous system autoimmunity. Ann. Neurol. 2010, 68, 369-383. [CrossRef] [PubMed]

31. Barr, T.A.; Shen, P.; Brown, S.; Lampropoulou, V.; Roch, T.; Lawrie, S.; Fan, B.; O'Connor, R.A.; Anderton, S.M.; Bar-Or, A.; et al. B cell depletion therapy ameliorates autoimmune disease through ablation of IL-6-producing B cells. J. Exp. Med. 2012, 209, 1001-1010. [CrossRef] [PubMed]

32. Molnarfi, N.; Schulze-Topphoff, U.; Weber, M.S.; Patarroyo, J.C.; Prod'homme, T.; Varrin-Doyer, M.; Shetty, A.; Linington, C.; Slavin, A.J.; Hidalgo, J.; et al. MHC class II-dependent B cell APC function is required for induction of CNS autoimmunity independent of myelin-specific antibodies. J. Exp. Med. 2013, 210, 2921-2937. [CrossRef] [PubMed]

33. Dittel, B.N.; Urbania, T.H.; Janeway, C.A., Jr. Relapsing and remitting experimental autoimmune encephalomyelitis in B cell deficient mice. J. Autoimmu. 2000, 14, 311-318. [CrossRef] [PubMed]

34. Van Olffen, R.W.; Koning, N.; van Gisbergen, K.P.; Wensveen, F.M.; Hoek, R.M.; Boon, L.; Hamann, J.; van Lier, R.A.; Nolte, M.A. GITR triggering induces expansion of both effector and regulatory CD4 ${ }^{+} \mathrm{T}$ cells in vivo. J. Immunol. 2009, 182, 7490-7500. [CrossRef] [PubMed]

35. Francisco, L.M.; Sage, P.T.; Sharpe, A.H. The PD-1 pathway in tolerance and autoimmunity. Immunol. Rev. 2010, 236, 219-242. [CrossRef] [PubMed]

36. Bebo, B.F., Jr.; Fyfe-Johnson, A.; Adlard, K.; Beam, A.G.; Vandenbark, A.A.; Offner, H. Low-dose estrogen therapy ameliorates experimental autoimmune encephalomyelitis in two different inbred mouse strains. J. Immunol. 2001, 166, 2080-2089. [CrossRef] [PubMed] 
37. Wang, R.X.; Yu, C.R.; Dambuza, I.M.; Mahdi, R.M.; Dolinska, M.B.; Sergeev, Y.V.; Wingfield, P.T.; Kim, S.H.; Egwuagu, C.E. Interleukin-35 induces regulatory B cells that suppress autoimmune disease. Nat. Med. 2014, 20, 633-641. [CrossRef] [PubMed]

38. Collison, L.W.; Workman, C.J.; Kuo, T.T.; Boyd, K.; Wang, Y.; Vignali, K.M.; Cross, R.; Sehy, D.; Blumberg, R.S.; Vignali, D.A. The inhibitory cytokine IL-35 contributes to regulatory T-cell function. Nature 2007, 450, 566-569. [CrossRef] [PubMed]

39. Piccio, L.; Naismith, R.T.; Trinkaus, K.; Klein, R.S.; Parks, B.J.; Lyons, J.A.; Cross, A.H. Changes in B- and T-lymphocyte and chemokine levels with rituximab treatment in multiple sclerosis. Arch. Neurol. 2010, 67, 707-714. [CrossRef] [PubMed]

40. Zhang, A.H.; Skupsky, J.; Scott, D.W. Effect of B-cell depletion using anti-CD20 therapy on inhibitory antibody formation to human FVIII in hemophilia A mice. Blood 2011, 117, 2223-2226. [CrossRef] [PubMed]

41. Chamberlain, N.; Massad, C.; Oe, T.; Cantaert, T.; Herold, K.C.; Meffre, E. Rituximab does not reset defective early B cell tolerance checkpoints. J. Clin. Investig. 2016, 126, 282-287. [CrossRef] [PubMed]

42. Marino, E.; Silveira, P.A.; Stolp, J.; Grey, S.T. B cell-directed therapies in type 1 diabetes. Trends Immunol. 2011, 32, 287-294. [CrossRef] [PubMed]

43. Pescovitz, M.D.; Greenbaum, C.J.; Krause-Steinrauf, H.; Becker, D.J.; Gitelman, S.E.; Goland, R.; Gottlieb, P.A.; Marks, J.B.; McGee, P.F.; Moran, A.M.; et al. Type 1 Diabetes TrialNet Anti-CD20 Study Group. Rituximab, B-lymphocyte depletion, and preservation of beta-cell function. N. Engl. J. Med. 2009, 361, 2143-2152. [CrossRef] [PubMed]

44. Mizoguchi, A.; Mizoguchi, E.; Smith, R.N.; Preffer, F.I.; Bhan, A.K. Suppressive role of B cells in chronic colitis of T cell receptor alpha mutant mice. J. Exp. Med. 1997, 186, 1749-1756. [CrossRef] [PubMed]

45. O'Garra, A.; Chang, R.; Go, N.; Hastings, R.; Haughton, G.; Howard, M. Ly-1 B (B-1) cells are the main source of B cell-derived interleukin 10. Eur. J. Immunol. 1992, 22, 711-717. [CrossRef] [PubMed]

46. Zarek, P.E.; Huang, C.T.; Lutz, E.R.; Kowalski, J.; Horton, M.R.; Linden, J.; Drake, C.G.; Powell, J.D. A2A receptor signaling promotes peripheral tolerance by inducing T-cell anergy and the generation of adaptive regulatory T cells. Blood 2008, 111, 251-259. [CrossRef] [PubMed]

47. Ohta, A.; Kini, R.; Ohta, A.; Subramanian, M.; Madasu, M.; Sitkovsky, M. The development and immunosuppressive functions of $\mathrm{CD}^{+} \mathrm{CD}^{+} 5^{+} \mathrm{FoxP}^{+}$regulatory $\mathrm{T}$ cells are under influence of the adenosine-A2A adenosine receptor pathway. Front. Immunol. 2012, 3, 190. [CrossRef] [PubMed]

48. Deng, S.; Moore, D.J.; Huang, X.; Lian, M.M.; Mohiuddin, M.; Velededeoglu, E.; Lee, M.K., 4th; Sonawane, S.; Kim, J.; Wang, J.; et al. Cutting edge: Transplant tolerance induced by anti-CD45RB requires B lymphocytes. J. Immunol. 2007, 178, 6028-6032. [CrossRef] [PubMed]

49. Zhao, G.; Moore, D.J.; Lee, K.M.; Kim, J.I.; Duff, P.E.; O'Connor, M.R.; Hirohashi, T.; Lei, J.; Yang, M.; Markmann, J.F.; et al. An unexpected counter-regulatory role of IL-10 in B-lymphocyte-mediated transplantation tolerance. Am. J. Transplant. 2010, 10, 796-801. [CrossRef] [PubMed]

(C) 2017 by the authors; licensee MDPI, Basel, Switzerland. This article is an open access article distributed under the terms and conditions of the Creative Commons Attribution (CC BY) license (http:/ / creativecommons.org/licenses/by/4.0/). 